\title{
Human Life Philosophy in Worship Rituals of the Ede People in Buon Ma Thuot - Highlands, Vietnam
}

\author{
PhD student Mai Trong An Vinh \\ Hanoi National University of Education, Viet Nam
}

\begin{abstract}
The cultural and spiritual life of the Ede people is very rich and unique. Therefore, the implementation of the Ede people's worship rituals is quite common. These rituals embody the Ede people's profound human life philosophies about human and human life. But now the Ede people's worship rituals have been transformed through the process of cultural exchange and contact with other ethnic groups. The regular practice of worship rituals on the one hand contributes to preserving and promoting the values in the Ede people's traditional culture, on the other hand, it is also one of the factors leading to superstitious actions, which negatively affects the healthy development of spiritual and cultural elements, hinders the construction of an advanced Vietnamese culture imbued with national identity in a more or less manner. Therefore, the research for objective view in a scientific perspective on human life philosophy in the Ede people's worship rituals is necessary to contribute to the explanation of the formation of the worship rituals and human life meaning of ritual practice steps. It is one of the important bases for cultural management agencies to devise appropriate guidelines and policies to preserve and promote human life values in the Ede people's worship rituals in Buon Ma Thuot in the current period.
\end{abstract}

Keywords: philosophy; human life; the Ede people; ritual; worship.

DOI: $10.7176 /$ RHSS/10-4-11

Publication date: February $29^{\text {th }} 2020$

\section{Introduction}

The Ede people are the second most populous ethnic group in the Central Highlands, reside mainly in Dak Lak province, especially in Buon Ma Thuot. The Ede people's cultural activities are quite rich and diverse. In particular, the implementation of worship rituals is quite common and regular in the cultural and spiritual life of this ethnic group. Worship rituals show the Ede people's profound human life philosophy. However, in the context that Vietnam has been increasingly integrating with the world, the Ede people's culture has conditions to interact and exchange with other cultures, making the Ede people's traditional culture become faded for the past time, including the worship system. The study of the philosophy of human life in the worshiping ceremony of the Ede people will partly explain the basis of formation, existence and movement trend of this culture in order to preserve and promote cultural identity. of the Ede people, in order to meet the development requirements of Vietnam in the current integration period.

\section{Research content}

\subsection{Some related concepts}

\subsubsection{Concept of human life philosophy}

* Philosophy

Dictionary and noun of Philosophy of author Tran Van Hien Minh (1966) describe the concept philosophy is a profound and magical argument of a good theory of an activity, a phenomenon, a gesture ${ }^{l}$. And Vietnamese dictionary of the Institute of Linguistics with chief editor named Hoan Phe (2012) defines that: philosophy is understood in two meanings: First, philosophy is a philosophical argument; Secondly, philosophy is the common human concept of human life and social issues ${ }^{2}$.

From the above concept of philosophy, we can give some following philosophical characteristics: Philosophy is a philosophical argument, a part of philosophy; Philosophy is common views of human life and social issues; Philosophy is a concise and brief summary of origin, nature, purpose ... of an activity, a phenomenon or a certain gesture.

* Human life

According to Vietnamese dictionary of Vietnam Academy of Social Sciences with chief editors named Nguyen Ton Nhan and Phu Van Han, Human life means the life of human, with human life meaning ${ }^{3}$. And Vietnamese dictionary of the Institute of Linguistics with chief editor named Hoang Phe (2012) defines that human

\footnotetext{
${ }^{1}$ Quoted by Tran Van Hien Minh (1966), Dictionary and Noun of Philosophy, Bookcase Get to the Open Sea, Nguyen Ba Tong Printing House, Saigon, pp. 280 .

${ }^{2}$ Quoted by Hoan Phe (chief editor, 2012), Vietnamese Dictionary, Institute of Linguistics, Vietnam's Encyclopedia Publishing House, Hanoi, pp.1323.

${ }^{3}$ Quoted by Nguyen Ton Nhan \& Phu Van Han (co-chief editor, 2013), Vietnamese Dictionary, Southern Institute of Social Sciences, Vietnam's Encyclopedia Publishing House, Hanoi, pp.788.
} 
life is the life of human'.

* So the human life philosophy is the most common and profound concept of people about human and life through the process of summarizing from real life. Human life includes not only the life of people and life of people but also humanity. Human life is manifested in the following aspects: First, life of people that is the basic element sustaining survival of people; Secondly, living of people. The purpose of living is not only to do good for oneself but also to make humanity become better. Living here is a living of innermost feelings and a living of outer feelings, also called spiritual living and material living; Thirdly, direction of people, toward a certain target.

\subsubsection{Worship ritual concept}

\section{* Ritual}

The Vietnamese Dictionary of the Dictionary of Vietnamese Dictionary points out the concept of a ritual as the etiquette and procedure of a ceremony ${ }^{2}$. And the General Anthropology curriculum of the University of Social Sciences and Humanities in Ho Chi Minh City states that a ritual in a certain extent as well as customs and practices, is the conventions that is repeated into habits, deeply ingrained into religious consciousness and socialcultural life $e^{3}$.

The ritual is formed together with human society, in which man is the subject of society. The ritual is often performed in the spiritual life of each ethnic group. Almost all ethnic groups in the world have rituals of varying degrees. The ritual is a common word, meant to express the established communication patterns of one or more people for one or more others and for one or more gods, the supernatural being. The ritual consists of many combined rites. Nghi means majesty, appearance, modesty and exemplary. The rite is the implementation of the rules, the pattern that the ancients had done; is a form of social organization. Thus, the Ritual is understood as the rites when performing the ceremony, converging all the elements of spiritual culture.

The anthropologist E.B.Tylor in his original work of Culture said that the ritual is a means of communication with soul entities ${ }^{4}$ and it is best to put faith in spiritual entities as a minimum definition of religion ${ }^{5}$. And A.A Radugin in Dictionary of Polytechnic Culture said about the ritual as follows: the ritual appears in theology to demonstrate the effective relationship between everyday life and the supernatural. The ritual is passed down not only in religion but also in life ${ }^{6}$.

According to the needs of the spiritual life, in response to both fear and desire of the divine gift, humans have formed a belief system and a ritual system. The ritual is passed down not only in religion but also in daily life, especially in traditional folklore. Cultural researchers have divided many different types of rituals: Agricultural ritual; Fishery ritual; Ritual of life cycle; Ritual of worshiping progenitor; Ritual of worshiping ancestors,...

The ritual plays an important role in the cultural identity of a clan and a people. The ritual is the overall picture of conduct, psychological identity and ethical norms of a clan and a people. Of course, in the process of campaigning according to the history's flow, due to the objective and subjective effects, sacredness, form, content of the ritual of each clan, each ethnic group have certain changes because cultural identity is not immutable but cultural identity is what was created through each historical period.

- Worship

Vietnamese dictionary of Nguyen Ton Nhan \& Phu Van Han says that worship is worshiping with rituals and worshiping ${ }^{7}$. As for the Vietnamese dictionary of the Institute of Linguistics, edited by Hoan Phe, it is said that worshiping is to pay homage to a god, a sacred object or the soul of a dead person in the form of rituals or worship according to customs or beliefs ${ }^{8}$ and offering is offering offerings to the dead or spirits of a dead person, according to beliefs or traditional customs 9 .

The worship is a form of ritual that expresses people's beliefs in the spirit world. This is a form of expressing the most universal belief. The form of worship has occurred since the appearance of human society. Worship is a traditional ethic of every individual and nation. The worship is the highest form of rituals manifested to the divine world, which is also a good teaching, the foundation for human morality in life. Worshiping means showing respect to our ancestors, ancestors, and saints who have contributed to the country and the gods for whom

\footnotetext{
${ }^{1}$ Quoted by Hoan Phe (chief editor, 2012), Vietnamese Dictionary, Institute of Linguistics, Vietnam's Encyclopedia Publishing House, Hanoi, pp.915

${ }^{2}$ Quoted from the Center of Dictionary (2007), Vietnamese Dictionary, Danang Publisher, Da Nang, Page 355.

${ }^{3}$ Quoted from Ho Chi Minh City University of Social Sciences and Humanities (2008), General Anthropology Curriculum, Ho Chi Minh City National University Publishing House, Page 24.

${ }^{4}$ Quoted from E.B.Tylor (2001), Primitive Culture, National Culture Publishing House, Hanoi, Page 946.

${ }^{5}$ Quoted from E.B.Tylor (2001), Primitive Culture, National Culture Publishing House, Hanoi, Page 947.

${ }^{6}$ Quoted from A.A. Radugin (translator Vu Dinh Phong, 2002), Dictionary of Cultural Science, Institute of Literature and Art, Hanoi, pp.326

${ }^{7}$ Quoted from Nguyen Ton Nhan \& Phu Van Han (co-editor, 2013), Vietnamese dictionary, Southern Institute of Social Sciences, Polytechnic Dictionary Publishing House, Hanoi, Page 1049

${ }^{8}$ Quoted from Hoan Phe (chief editor, 2012), Vietnamese Dictionary, Institute of Linguistics, Polytechnic Dictionary Publishing House, Hanoi, Page 1222.

${ }^{9}$ Quoted from Hoan Phe (chief editor, 2012), Vietnamese Dictionary, Institute of Linguistics, Polytechnic Dictionary Publishing House, Hanoi, Page 298.
} 
we have faithfully sent. Offering is also understood in the sense of offering sacrifices, offering gifts to the ancestors, ancestors, ancestors, and saints with meritorious services to the country... whom we always respect and pray for their witness to our sincerity. Within the scope of this article, the author uses the word cozy in the sense of offering.

From the above analysis, we can understand that the worship rituals is rituals and order of steps for conducting a ceremony for the predecessors, ancestors, sages and saints of the country and the gods, whom we always respect and pray for their witness to our sincerity.

\subsection{The Ede people in Buon Ma Thuot}

Buon Ma Thuot is the name of a "village" of Ede Kpa people. At the end of the nineteenth century, there was only one village with about 50 long houses managed by the sheik Ama Thuot. By the early years of the twentieth century, Buon Ma Thuot was no longer a single trade but gathered and developed dozens of other villages. However, Buon Ma Thuot is still a big village of the whole region and it is also governed by the sheik Ama Thuot ${ }^{1}$. Currently Buon Ma Thuot is a city under Dak Lak province, there are about 42 ethnic groups living, among the indigenous and Ede ethnic groups with the largest population ${ }^{2}$.

The Ede people is derived from the Malay speaking ethnic group in the Pacific Islands. Currently, the Ede people still have matriarchy. The Ede people include the following main groups: Ede Kpa, residing mainly in Buon Ma Thuot and scattered in districts of Krong Ana, Krong Pak, Cu Mgar, ... Dak Lak province; Edham Adham, residing mainly in districts Krong Buk, Cu Mgar, Krong Nang, ... of Dak Lak province; Ede Mdhur, mainly residing in the district of Mrak in the eastern part of Dak Lak province; Ed Bih, mainly residing in Krong Ana and Krong Kno districts of Dak Nong province; Ede Krung, residing mainly in the districts of Ea Hleo, Krong Buk of Dak Lak province ... In daily life, the Ede people follow matriarchy, so children bring mother's family. The wife will marry a husband for her and the man after marriage will live with his wife's family. The Ede people 's livelihood in Buon Ma Thuot used to be mainly cultivated but today, they also process agricultural products, grow industrial crops such as coffee, rubber, pepper, cocoa... The main livelihood of the Ede people in Buon Ma Thuot is mainly agriculture. The worship system of the Ede people is very diverse and rich, however within the scope of this paper, the author focuses on the life cycle and agricultural rituals of this ethnic group, as these are the two most important rituals in the life of the Ede people.

\subsection{Outline of life cycle ritual and agricultural ritual of the Ede people in Buon Ma Thuot 2.3.1. Outline of life cycle ritual}

For the Ede people, the life-cycle ritual plays an important role in their lives because it is associated with every transition in each individual's life and greatly affects each member of the family. The Ede people believe in the sacredness of the gods, where rituals provide a bridge for humans to access the gods. The life cycle ritual is usually divided into three main stages: birth, maturity and death.

* The stage of birth, including rituals: ritual for the mother and fetus's health, ritual for fetus protection, ritual for the mother after giving birth, ritual for midwive's health, ritual for the mother's health, ritual for blowing ears, ritual for naming child.

* The stage of maturity, including rituals: ritual for children's maturity, ritual for wearing necklace, ritual for teeth flossing, ritual for offer, ritual for wedding.

* The stage of death, including rituals: ritual for dead, ritual for the dead by accident, ritual for buring the dead, ritual for bỏ mả.

\subsubsection{Outline of agricultural ritual}

The Ede people have a way of dividing the time in agricultural production based on the cycle of twelve bright moons and one bright moon corresponding to one month as per year. The first bright moon they usually spend time to play and rest mainly; on the second bright moon, they often spend time in the forest to hunt and hunt for wild animals as a food reserve for the rainy season; the third bright moon officially started the Ede people's agricultural cycle, they started clearing the fields and reclaiming the moon this morning to prepare for the new crop to begin; just like that, on the fourth bright moon, Ede people spend time to clear fields, clear the fields and clear the fields to prepare for sowing and planting rice; on the fifth bright moon, they often organize a ritual to pray for rain and an worship for the first rain; on the sixth bright moon, the Ede people often sow their rice and plant crops; On the seventh bright moon, the Ede people often spend this time weeding on milpas; on the eighth bright moon, the Ede people often cultivate and pray for the gods to protect the cultivation; the nineth bright moon is an occasion for the Ede people to hold a new rice-worshiping; on the tenth bright moon, they wait to harvest rice and other crops; on the eleventh bright moon, the whole village comes together to harvest crops and pluck rice, this moon was also an opportunity for them to hold a ritual to thank the ancestors and the gods and on the last full moon in a year, when the harvest of crops and plucking of rice is completed, this is the opportunity for Ede

\footnotetext{
${ }^{1}$ In Ede, Ama means father, Y Thuot refers to a son named Thuot - Buon Ma Thuot is an abbreviation: Y Thuot father's village.

${ }^{2}$ Quoted from Provincial Party Committee - People's Council - People's Committee of Dak Lak Province (2015), Geography of Dak Lak Province, Social Sciences Publishing House, Hanoi.
} 
people to hold the ritual for importing rice into bamboo basket ${ }^{1}$. At each stage of shifting cultivation, at different times, the Ede people will conduct the corresponding rituals in order to pray to the gods to bless their cultivation with good rain and good weather. The Ede's agricultural rituals include the following main rites: ritual for the sylph; ritual for grassing; ritual for rice sowing; ritual for rice seed; ritual for paying for rain; ritual for the first rain; ritual for rice watering and New rice eating ceremony.

\subsection{Concept of human and living of the Ede's worship rituals in Buon Ma Thuot \\ 2.4.1. Concept of human}

\subsubsection{Concept of human origin}

The Ede people believe that the human being was created by Ae Die god who was the highest god of the Ede people, created the first human beings in the world and then, when a person died, his/her soul would go through 7 times of transformation and circulation, finally reborn into a human liffe by reincarnating into the daily life of his/her descendant. The end of a human cycle, that means one cycle ends to continue the beginning of a new human cycle. For the Ede people, death is in fact a preparation for a new beginning. The Ede people always tend to live in a nostalgic way, they think that the beauty of their ancestors is a really standard beauty, what created by their ancestors are standard values, so it's needed to preserve and maintain, worship rituals will help the Ede people preserve those values. Enhancing the role of traditional values is also the way that the Ede people return to the inner world to find the human origin.

\subsubsection{Concept of life and death}

\section{* Concept of life}

For the Ede people, life of a person is given by the Gods, so the Gods is the one who decides the existence, development and end of life of a person. Human and God have reciprocal and dialectical relationships, worship rituals are a means for people to communicate with God. Through their praying statements, people entrust their thoughts and aspirations to the Gods in order to expect the Gods to help people reach the limitlessness in life which is inherently limited. That thought of the Ede people becomes the truth for human life. The Ede people also hold the same concept, they always believe that life is a combination between body and soul, human life begins only when body and soul come together as one because thanks to which the human body only can function and think, for them, the human life is given by Ae Die God. The majestic vast natural world is the first object that makes human life become dependent, because things and phenomena in nature directly affect human life day by day, hour by hour, from the time when human was given life of the Gods. In the real life of the Ede people, they always feel that they are too small in nature, because they are often helpless in response to it, so from that, the Ede people often fear bad things course. Since then they have become a cult of nature, because they think that the good and phenomena in nature created by the Gods and worship rituals are a means for people to connect with the Gods to send their aspirations. The Ede people believe that human life is given by the Gods, a person is only considered to have life when he/she starts to have soul, so human life is decided by the soul. They also believe that human life comes from the soul, so the life of all species is determined by the soul, therefore, people have soul and the species also have sould. Hence, in the worship rituals of the Ede people, people conduct a life cycle ritual while rice also has a rice life cycle ritual. They believe that the rice is survived by the dominance of rice soul. Therefore, the Ede people have many ritauls related to the worship of rice soul, most typically rice seed worship ritual.

Rice seed worship ritual is an important ritual which reflects the concept of rice soul of the Ede people, this ritual is held in the family right after the rice sowing worship ritual is completed, in the rice sowing worship ritual, the Ede people not only worship the God of Rice but also worship other Gods to pray to the Gods to support their family and villagers to have favorable conditions and good harvest. The ritual is also performed at the Gah compartment $^{2}$ in a long house. The offerings for rice seed worship ritual are usually: a cup of ruơu cần (wine drunk out of a jar through pipes), a chicken, rice seed, secondary crop seed, a neohouzeaua tube, a hoe and two plants used to prick holes for sowing rice. When everything is ready, the host will knee down by side of a cup of ruợu cần and begins praying to Â Mtao Tlua God ${ }^{3}, H^{\prime}$ Bia Klu God ${ }^{4}$ and other Gods for coming to witness the ritual, when the praying is finished, the host will come to the praying tray and made praying statement in the second time, the offerings on the tray usually consist of a copper bowl mixed with chicken blood and ruơu cần, a boiled chicken, rice seed and other cereal seeds. The content of the second praying statement is similar to the previous one. At this time, the ritual host will hold a bowl of chicken blood copper mixed with wine to irrigate the seed species while praying to the Gods for coming to witness and bless the family to have a bumper crop, convenient and smooth agricultural cultivation. After completing the praying, everyone in the family will drink the first sip of rưou cần, the woman, the owner of the family, will drink the first sip of ruơu cần and then the rest

\footnotetext{
${ }^{1}$ Rice basket is woven from bamboo and neohouzeaua, with high walls, wide and round mouth, often with a lid.

${ }^{2}$ The half of main door of the long stilt house of the Ede people is called Gah that is the place of reception, common activities of the long house, is the place containing items such as main kitchen, guest chair, long chair (Kpan)...

${ }^{3}$ God of Rain.

${ }^{4}$ Fairy God
} 
of the family will do the same. After this ritual, the Ede people begins to bring rice seeds and other kinds of seeds to the milpas to sprinkle, sow and plant.

In the concept of the Ede people's life, they believe that when a person dies, his/her body will become ash and the soul will be still alive in the world of the dead and then the soul will transform into dew drops that bring the soul of the ancestor back to the secular world of the human being that is reincarnated into a child during the ritual of blowing air on baby's ears and naming ritual. The Ede people highly respect the ritual of blowing air on baby's ears because they believe that the ritual will help baby develop healthier, wiser and teach the baby good things. This is a very important ritual in the life of a person when born, this ritual is seen as a milestone in human life, the Ede people hold this ritual in order to expect the Gods to witness the fact that the village welcome by a new member. In addition, this is also an opportunity for the family to show the gratitude towards midwife for helping the mother have a successful delivery. And the naming ritual is usually held by the Ede people at the same time with the ritual of blowing air on baby's ears, they believe that when a person dies, after the soul is circulated after many times and in the last reborn in human life and becomes a descendant in the family, the sign of that rebirth is in the form of a dewdrop, so during the naming ritual for the child, the Ede people often take a leaf with a dew drop, place on the child's face and recall names of grandparents and ancestors ${ }^{1}$ until the child does behaviors such as smiling, swinging legs, swinging arms, etc., meaning that the child accepts and choose that name, or in other words the child chooses the soul of an ancestor with suc a name. From that moment, the name of the child appears to be officially given, but the family does not take exact name of the ancestor for the child but usually based on the syllable, for example, name of the ancestor is Y Sieng, then the child will be named Y Tieng.

* Concept of death

The Ede people believe that death is a departure from the life to return to the ancestral world ruled by two Gods named Bang Bdung and Bang Bdai, the rituals for the dead on this occasion are one of the most important and largest-scale rituals in the worship rituals of the Ede people because those are the affection of the survivors for the dead. The Ede people believe that there are two types of death: good death and evil death. Good death is the death due to old age, the death under the natural rule while evil death is the death caused by accidents on the road, meaning caused by the evil god. Because of such a concept, fro the funeral of the evil dead, the Ede people often hold more sketchily than they do for the good dead. The evil dead are usually not buried in the village's graveyard area and when the burial ceremony is completed, they do the grave leaving ceremony and the Ede people rarely dare to approach the grave. For the good dead, after conducting the ceremony of Entering the Coffin from one to three days (depending on the circumstance of each family), the dead will be buried. The Ede people often prepare a hen and a chick so that when lowering into the grave, the hen is dropped down in a coffin along with some cooked rice or rice with the idea of letting the dead take them to the afterworld as an asset, and the chick is released into the forest after finishing the lowering into the grave, the action symbolizes the release of the soul of the dead which implies that the soul of the dead will not return to disturb the survivors. When the coffin is lowered into the gEde, someone places a lining board onto the grave surface and fills it with soil. A big-bellied jar of wine with perforated bottom is placed at the gEde end and a bamboo tree perforated with inner bamboo eyes and then placed from the bottom to rise above the grave outlet above the end of the coffin for the purpose that the family of the dead will daily bring cooked rice, food, wine ... to pour into bamboo tubes interconnected to the grave with the concept of "feeding" the dead. The Ede people never abandon the soul of their relative ones, the care for the soul of their loved ones as their indispensable need. For them, the soul of the dead is cared for with the love of relative ones as they were still alive, the Ede people always believe that the soul of the dead will feel the love that their loved relatives give to them.

The statue of the one sitting with holding his/her chin and the statue of the one sitting with arms clasping knees are usually placed inside the Ede people's grave house, according to the Ede people, which is the symbol of fetus, symbolizing future birth and it is also a image contrary to the death present inside the grave house. That's the way the Ede people place life next to the death, because for them it is yin and yang harmony in death, the death is preparation for a new life. Thus, the rituals for the dead not only express the ideas in the death of the Ede people but also regulate the opposite relationship between life and death in the living of the Ede people, to make human life become more and more balanced and harmonious. The thought about two opposite sides in the Ede people's human life philosophy is the expression of the concept of dialectic movement and circulation between the life and the death. These things are expressed almost throughout the worship rituals of this ethnic group. To some extent, the human life philosophy in the worship rituals is the harmonization of relationships with two opposite sides in the living of the Ede people.

When the dead's coffin hasn't been brought to the burial ground, the residents in the village must not go to work. Those who come to help families with funerals, after burying the dead, must not go their home immediately

\footnotetext{
${ }^{1}$ The Ede people often name their children by names of grandparents, ancestors but they have to choose the names of those who are really rich and virtuous so that their children can are the same when the children grow up. Before the naming ritual také place, the children's parents tell the sorcerer the names the family want to name the children, so during the ritual practice, the sorcerer will recite the names in turn for the child to hear.
} 
but have to stay over night, and go home in the following morning but before cock-crow time. The Ede people believe that if they do so, the soul of the dead will not follow them home. The Ede people are very afraid of the fact that a baby is dead in the mother's womb or dead shortly after birth. Because they believe that it's a bad omen that will affect their families, lineages and villages so when the above mentioned happens, the families and lineages of both sides must be fully present to care for the complete burial of the corpse. The Ede people believe that the dead before the naming ritual is a person without any soul because the ancestor hasn't reincarnated into that child and that death is caused by the evil god and the death is called evil death. So the family has to conduct God worship ritual with common offerings including a goat (or dog), a big-bellied jar of wine and some other offerings, performed right at the place where the child dies. When performing this ritual, the ritual host orders the family to kill an animal for sacrifice, take blood to sprinkle on the land where the unfortunate event has just happened in order to drive away the evil god. After that, the dead will be buried immediately and then the family must conduct an worship ritual of letting bad luck out for the woman in childbirth and midwifes. In this ritual, two midwives and the woman in childbirth will drink the first sip of wine.

It can be said that the human life philosophy of death in the worship rituals of the Ede people is very special, the rituals related to death are the convergence point of folklore elements imbued with national identity of this ethic group. They believe that the world of the dead has also houses, villages, fields ... that world also has wives and husbands as the world of the survivors, so the Ede people have a custom of dividing properties to the dead.

\subsubsection{Concept of living of human in the worship ceremony of the Ede people in Buon Ma Thuot}

\subsubsection{Concept of the relationship between human and the universe}

The Ede people believe that the relationship between human and the universe mainly has the characteristics of Oriental philosophical thought, although the Ede people always have the thought of separating human from the universe as the philosophical thought of the West, but because the Ede people have a polytheistic religious tradition, they are often afraid and subdued by the natural world of the universe. They also believe that human can connect with the spirit world in the universe with worship rituals, praying statements to the Gods in ritual practice are the thoughts and aspirations of people who want to send to the Gods in the vast universe. The Ede people believe that the whole universe is a combination of 3 horizons, including the upper sky, middle ground and lower ground. On those 3 horizons, there are gods residing. For the Ede people, the sky horizon is reigned by Ae Die God, this is their ultimate God, Ae Die is the God who created human and all beings, Ae Die is also the Gods who gives all plant varieties for human. So for the Ede people, Ae Die is the God determining life and death of human, therefore they are very afraid of being punished by this God. In addition, there is also Ae Du God who is considered by the Ede people to be a wise god entrusted by the Ae Du God to resolve all contradictions in the human world, Ae Du is also the God guiding human rituals in the worship ceremony of the Ede people. For Ede people, these are two ultimate Gods in the universe, therefore, in most of the spirit prayers in the worship ceremony of the Ede people, names of these two Gods are prayed.

\subsubsection{Concept of the relationship between human and nature}

The Ede people from ancient times formed a lifestyle close to wild nature and pristine mountains and forests, so the relationship between the Ede people and nature is very close. Because of the concept of "all things with existence of Gods", the Ede people's cultural life is very diverse and rich, they always worship the Gods in order for the Gods to give them good things in life. The Ede people always believe that the Gods are the supernatural beings that control the power of nature. Worship rituals are also the Ede people's behavior towards the Gods, which is their behavior towards nature by the human life philosophies in the worship rituals. These philosophies are summarized by the Ede people in daily life through their labor, creation and survival process. For them, each plant type in the nature has its own meaning and strength because each type has a God residing inside. The Ede people also believe that each type in nature has its own life cycle, human has a ritual of human life cycle, so plants in nature also have its own life cycle ritual. They believe that the ancient and great trees that have lived for a long time in nature are the symbol of everlasting eternity, the konia tree in the life of the Ede people is typical, this tree has great spiritual significance for the Ede people, they believe that it's the residence of the Gods and the souls of the dead so it can't be cut down. Therefore, when the Ede people reclaim land for cultivation, they often leave konia tree with the above meaning. These things have created a harmonious connection between the Ede people and nature in an increasingly stable manner. For the Ede people, all things and phenomena in nature have their own meanings, for them, nature is an invaluable asset that gives life to human, so in the spiritual prayers, the Ede people often teaches the descendants to respect, protect and preserve nature. Worship rituals are the interaction between human and gods in a certain space and time, in the course of their existence and development, the Ede people have to rely on nature. So their human life philosophy is based on their perceptions of the relationship between human and nature.

\subsubsection{Concept of human life in relation to society}

From distant past to present day, the Ede people's family has matriarchal tradition, so the Ede people's social community operates under matrilineal family's custom. The Ede people's production level is agricultural production on the upland fields, so this ethnic group has a social organization formed under the model of "village" 
or "mountain village", which is the only social organization and is also the basic place of residence of the Ede people until now. The production level of an ethnic group is always associated with the social organization of that ethnic group, the Ede people's mountain village is a collection of long houses made entirely of natural materials. The number of long houses more or less depending on the size of the mountain village. The leader in charge of managing the mountain village is the owner of the water wharf (po pin ea), everything big or small in the mountain village must be consulted the owner of the water wharf. The Ede people's long house is the place off residence of a collection of small relative families living together. The space for organizing the Ede people's worship rituals usually mainly takes place in the long house and in some other places such as water wharf and grave house... All activities in daily life are carried out by the Ede people in the scope of the mountain village, do not completely invade other mountain villages. The labor division by sex and age of the Ede people is relatively clear, a woman proactively marries a man but the man must have the duty to honor the wife's family. In important family events, typically in the occasion of holding worship rituals, the woman (head of the family) often sends a man to perform important tasks on her behalf. The man in this case may be the husband, older brother or younger brother of the woman, head of the family. The organization principle in the Ede people's family focuses on the role of the woman, the head of the family is always a reputable elderly woman, who plays a role in assigning household tasks, besides the head of the family is also responsible for managing food, distributing assets to family members when necessary and especially takes the main responsibility for educating the descendants in the family. However, the role of a man is also indispensable in the Ede people's matriarchal family because the assets of ancestors only are transferred heirship for the woman but the man has right to use, thus the prestige of the man in the Ede people's familiy is created by his wife side and his wife side's family but not entirely from his mother or the family of his mother. Social organization model of the Ede people is still rudimentary and follows matriarchy, they manage social relationships with customary law system and worship rituals, the Ede people teach their children to love, respect, and help each other in difficult times...

\section{Conclusion}

Because of the concept of " all things with existence of Gods", every living of Ede person must undergo a lot of worship rituals. The human life philosophy filled within these rituals is to express and send to the Gods the Ede's inmost feelings and expectations. The Ede people's human life concepts creates a delicate sympathy between human and spirit, it personifies all phenomena and things surrounding human life, thereby creating emotions that positively impact the Ede people's life in the community - society. Worship rituals are the results summarized by the ancient Ede people's labor and creative practices from ancient times with the human life philosophies that carry dialectical materialism element and reflect the objective rules in life about human and human life in relation to the universe, with nature and with the community - society. The study of human life philosophy in the Ede people's worship rituals has a theoretical and practical meaning in preserving and promoting the values in the Ede people's cultural identity in Buon Ma Thuot in the current period.

\section{Bibliography}

1. A.A. Radugin (translator Vu Dinh Phong, 2002), Dictionary of Cultural Science, Institute of Literature and Art, Hanoi

2. Anne de hautec loque (2004), the Ede people - a matriarchal society, Ethnic Culture Publishing House, Hanoi.

3. Be Van Dang (1983), Initially explaining cultural intercourse, Journal of Ethnography, No. 3.

4. E.B.Tylor (2001), Primitive Culture, National Culture Publishing House, Hanoi.

5. Nguyen Ton Nhan \& Phu Van Han (co-editor, 2013), Vietnamese dictionary, Southern Institute of Social Sciences, Polytechnic Dictionary Publishing House, Hanoi

6. Hoan Phe (chief editor, 2012), Vietnamese Dictionary, Institute of Linguistics, Polytechnic Dictionary Publishing House, Hanoi

7. Ngo Duc Thinh (2007), Cultural areas of the Central Highlands, Youth Publishing House, Ho Chi Minh City

8. Ngo Duc Thinh, Le Van Ky and Nguyen Quang Le (2007), Traditional customs of some ethnic minorities in the South Central Highlands, Hanoi Ethnic Publishing House.

9. Ngo Duc Thinh (editor, 1992), Ede folklore, Ethnic culture publishing house, Hanoi.

10. Nguyen Huu Tham (2003), Khan Dam Hunt and Khan Dam Kteh Mlan, volume 1, National Political Publishing House, Hanoi.

11. Ho Chi Minh City University of Social Sciences and Humanities (2008), General Anthropology Curriculum , Ho Chi Minh City National Publishing House.

12. Provincial Party Committee - People's Council - People's Committee of Dak Lak Province (2015), Address of Dak Lak Province, Social Sciences Publishing House, Hanoi.

13. Nguyen Tuan Triet 2000), Historical development of Malay - Da Dao ethnic group, Social Science Publishing House, Hanoi.

14. Le Trung Vu (1995), Ede Folk Festival, Publishing House of Ethnic Culture, Hanoi. 